\title{
Identification of circulating regulatory $T$ lymphocytes with membrane markers - a new multiparameter flow cytometry protocol
}

\author{
Agnieszka Piekarska ${ }^{1} \oplus$, Michaël Pérès ${ }^{2,3}{ }^{\oplus}$, Magdalena Toton ${ }^{4}$, Malgorzata Kulczycka ${ }^{4}$, \\ Krzysztof Lewandowski ${ }^{5}$, François Vergez ${ }^{2,3}$
}

${ }^{1}$ Department of Hematology and Transplantology, Medical University of Gdansk, Gdansk, Poland

${ }^{2}$ Cancer Research Center of Toulouse, Inserm UMR 1037, CNRS ERL 5294,

University of Toulouse, Oncopole, Toulouse, France

${ }^{3}$ Laboratoire de Génétique des Hémopathies, Institut Universitaire du Cancer Toulouse

- Oncopole, Toulouse, France

${ }^{4}$ Laboratory of Hematology, University Clinical Centre, Gdansk, Poland

${ }^{5}$ Department of Laboratory Medicine, Medical University of Gdansk, Gdansk, Poland

\begin{abstract}
Introduction. Regulatory $\mathrm{T}$ cells (Tregs) are a unique $\mathrm{CD} 4^{+} \mathrm{T}$ cell subset involved in the regulation of immune responses. The traditional immunophenotype used to define Tregs includes $\mathrm{CD} 4{ }^{+} \mathrm{CD} 25^{\text {high }}$ and the expression of the transcription factor Forkhead box protein 3 (FoxP3). A complex technique of intracellular staining, transient upregulation of FoxP3 in activated conventional T lymphocytes (Tcons), and the omission of naïve CD45RA ${ }^{+}$ Tregs with downregulated FoxP3 activity but a demethylated FOXP3 promoter region may lead to inaccurate quantification. In an attempt to meet the need for a reliable and simplified enumeration strategy, we investigated different membrane markers to capture the entire Treg compartment and to identify subpopulations of Tregs. Material and methods. Analyses were performed on whole blood. Tested gating strategies were based on the expression of the following membrane antigens: CD45, CD3, CD4, CD25, CD127, CD26, CD6, CD39, CD71, HLA-DR, CD45RA and CD31. Double controls with FoxP3 were performed.

Results. The final enumeration panel consisted of the membrane markers CD45, CD3, CD4, CD25, CD127, $\mathrm{CD} 26, \mathrm{CD} 39, \mathrm{CD} 45 \mathrm{RA}$ and $\mathrm{CD} 31$. A deep analysis of $\mathrm{T}$ cells with the $\mathrm{CD} 4{ }^{+} \mathrm{CD} 25^{+} \mathrm{CD} 127^{\text {low/ }}-\mathrm{CD} 26^{\text {low/ }} \mathrm{CD} 45 \mathrm{RA}{ }^{-}$ immunophenotype revealed high expression of FoxP3 and/or CD39, while cells with the naive immunophenotype, $\mathrm{CD} 4{ }^{+} \mathrm{CD} 25^{+} \mathrm{CD} 127^{\text {low/ } /} \mathrm{CD} 26^{\text {low/ }}-\mathrm{CD} 45 \mathrm{RA}^{+}$, presented lower expression of suppressor markers. Antigen CD31 is considered to be a valuable membrane marker of thymus-derived Tregs.

Conclusions. The presented 9-color panel that can be easily applied in laboratories enables reliable enumeration of Tregs with additional information about the functionality, maturity and origin of T regulatory cells. (Folia Histochemica et Cytobiologica 2021, Vol. 59, No. 2, 75-85)
\end{abstract}

Key words: $\mathrm{T}$ regulatory cells; enumeration; flow cytometry; 9-color panel; CD31

\footnotetext{
Correspondence address: Agnieszka Piekarska, MD, $\mathrm{PhD}$

Department of Hematology and Transplantology,

Medical University of Gdansk

Smoluchowskiego 17, 80-214 Gdansk, Poland

fax: +48585844350

e-mail: agnieszka.piekarska@gumed.edu.pl
}

This article is available in open access under Creative Common Attribution-Non-Commercial-No Derivatives 4.0 International (CC BY-NC-ND 4.0) license, allowing to download articles and share them with others as long as they credit the authors and the publisher, but without permission to change them in any way or use them commercially. 


\section{Introduction}

Regulatory $\mathrm{T}$ cells (Tregs) are a unique $\mathrm{CD}^{+} \mathrm{T}$ cell subset involved in the regulation of immune responses. This subpopulation is fundamental for the development of immune tolerance after allogeneic hematopoietic cell transplantation (alloHCT) [1]. There are also many reports showing a correlation between clinical response to therapies applied in certain inflammatory conditions and increasing levels of circulating Tregs [2]. Extracorporeal photopheresis (ECP), offered to patients with graft-versus-host disease (GVHD) resistant to standard immunosuppressive therapy, is one of the best examples [3-5]. Among the complex mechanisms of immunomodulation promoted by ECP, the induction of Tregs seems to play a crucial role $[6,7]$. In addition to the measurement of the clinical response to therapies influencing the expansion of Tregs, the evaluation of immunological status during treatment would give additional arguments for the maintenance or modification of immunosuppressive treatment [8-12]. Therefore, clinicians have highlighted the need for a reliable and accurate strategy for Treg enumeration and monitoring that can be applied in routine everyday practice [13].

The transcription factor Forkhead box protein 3 (FoxP3) is a traditional marker for the identification of Tregs with suppressor activity by flow cytometry. Given that FoxP3 is an intracellular molecule, its detection requires a complex technique of fixation and permeabilization, which may give inaccurate quantification owing to inevitable cell loss and reduced fluorescence of the antibody conjugates [14, 15]. DURAClone staining technology reduces pipetting errors and stabilization issues but it is not available in every laboratory $[15,16]$. Moreover, flow cytometry may not be sensitive enough to detect all FoxP3 proteins, and activity below the level of detection is omitted. The results vary and may be difficult to compare among different laboratories or over time in the same laboratory. Moreover, quantification is imprecise because FoxP3 is transiently upregulated in activated effector $\mathrm{T}$ lymphocytes (conventional $\mathrm{T}$ cells; Tcons) [17]. CD127 antigen has been described as a surrogate marker of FoxP3 because there is an inverse correlation between $\mathrm{CD} 127$ and FoxP3 expression $[16,18]$. However, it has also been demonstrated that $\mathrm{T}$ lymphocytes of phenotype $\mathrm{CD} 25^{\text {high }} \mathrm{CD} 127^{\text {low } /-}$ with FoxP3 $3^{\text {low/- }}$ are equally suppressive [19-21]. Additionally, naïve CD45RA ${ }^{+}$Tregs with downregulated FoxP3 activity have "hidden" but stable suppressor potential, as demonstrated by high levels of FOXP3 mRNA and a demethylated $F O X P 3$ promoter region $[22,23]$. Taking these data together, FoxP3 expression is not always sufficient for the identification and enumeration of circulating functional Tregs in humans, and the expression of $\mathrm{CD}^{+} \mathrm{CD} 25^{+} \mathrm{CD} 127^{\text {low/ }}$ seems to be more accurate for this purpose [16, 24].

We aimed to investigate the membrane antigens that would give comparable and reliable enumeration of the entire Treg compartment and the identification of Treg functional subpopulations.

\section{Materials and methods}

Design of the marker molecules' panel. The backbone panel contained antigens CD25 and CD127 and CD45RA, gated on $\mathrm{CD} 45^{+} \mathrm{CD} 3{ }^{+} \mathrm{CD} 4{ }^{+}$cells. Antigens $\mathrm{CD} 25$ and $\mathrm{CD} 127$ are utilized to identify Tregs in many laboratories, but this simplified analysis seems to be insufficient [19, 20, 25]. Therefore, the tested panel was widened with the antigens CD26, CD6, CD39, CD31, and HLA-DR, and a double control with FOXP3, to better characterize the gated subgroups. The choice of CD26, CD6 and CD39 was justified because these specific surface markers were already tested for the isolation of Tregs by cell sorting, e.g., for therapeutic purposes. The suppressor activity of those sorted cells was already validated [25-27]. The choice of antigens CD45RA and CD31 was designed to distinguish naïve Tregs from effector/memory Tregs, and thymus-derived ( $\mathrm{t}$ )Tregs from induced, periphery-derived (p)Tregs [22, 28]. The expression levels of CD71 and HLA-DR were included as activation markers [29].

Blood samples. Twenty-one peripheral blood samples were collected from healthy volunteers into vacutainers with EDTA as an anticoagulant. The final panel was tested on blood samples from 10 patients treated for chronic GVHD after alloHCT. All analyses were performed on whole blood. The study was conducted in conformance with the latest Declaration of Helsinki ethical guidelines and was approved by the Bioethical Committee of the Medical University of Gdansk (decision number NKBBN/413/2016).

Flow cytometry and sample analysis. Samples comprising $200 \mu \mathrm{l}$ of whole blood were incubated with the following antibodies/conjugates in various combinations depending on the staining protocol tested: CD3-BV421 (clone UCHT1), CD45-BV510 (clone H130) (both from BioLegend), CD4-PECy7 (clone SK3), CD25-PerCP Cy5.5 (clone M-A251) (both from Beckman-Coulter), CD26-FITC (clone M-A261), CD31-PE (clone WM59), CD39-PE-CF594 (clone TU66), CD39-PE-CF594 (clone TU66), CD39APC (clone TU66), CD6-Alexa Fluor 647 (clone M-T605), CD45RA-Alexa Fluor 700 (clone HI100), CD127-APC-H7 (clone R3434), and CD3 Pacific Blue (clone UCRH1) (all from BD Biosciences). Incubation was followed by cell lysis with a solution of ammonium chloride and two washes 


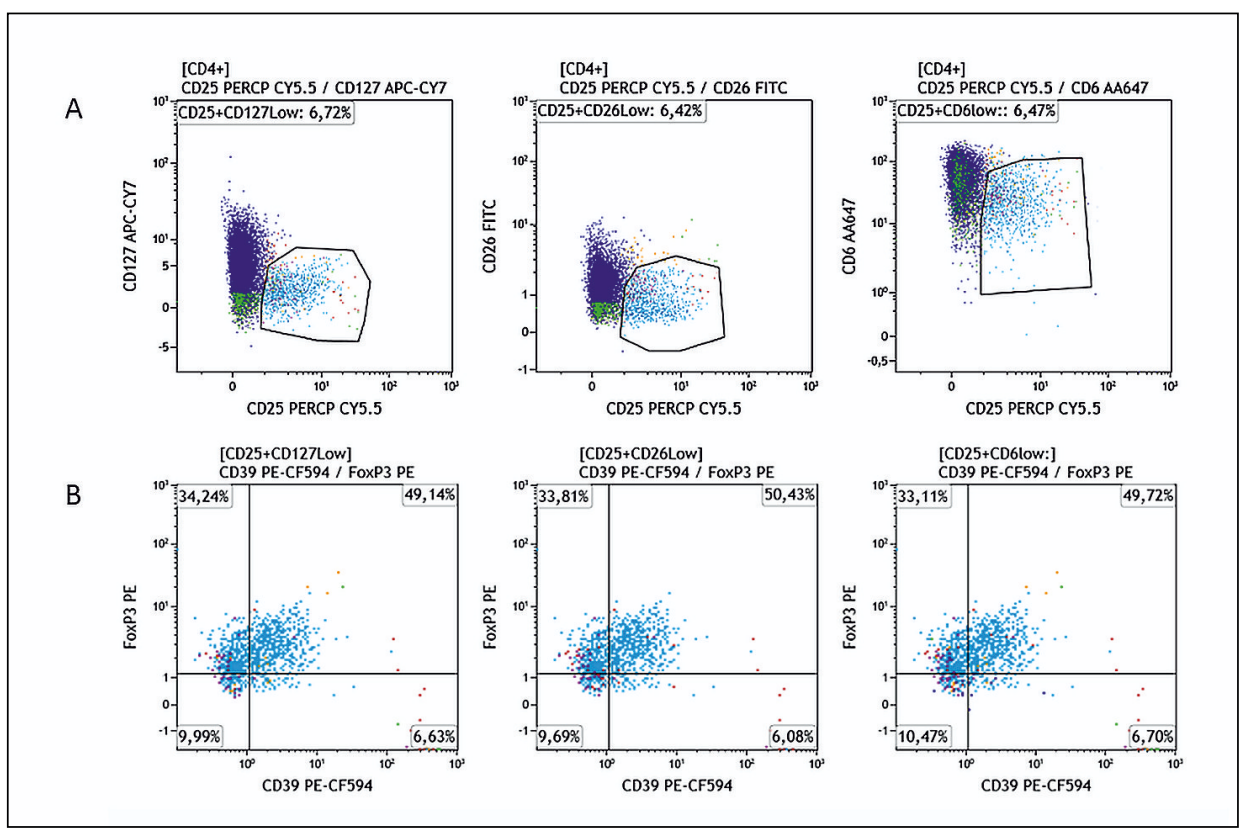

Figure 1. Comparison of three dot plots for initial Treg gating. A. Presentation of initial gating based on the CD25 expression and one of three negative Treg-associated markers (CD127 or CD26 or CD6); B. FoxP3 and CD39 expression of cells gated on CD25-positivity and negative Treg-associated markers (CD127 or CD26 or CD6)

before cell resuspension. Specimens with membrane staining proceeded to the acquisition step. Samples requiring intracellular staining were fixed and permeabilized with Fix/Perm Buffer and washed with the Perm Buffer from a FoxP3 staining kit (eBioscience). Staining with FoxP3-PE (clone PCH101; eBioscience) was performed in Perm Buffer before cytometer acquisition.

For the data obtained at the University of Toulouse (Toulouse, France), cells were acquired on 10-color Navios (Beckman Coulter). For the data obtained at the Medical University of Gdansk (Gdansk, Poland), cell acquisition was performed on a Becton Dickinson 12-color BD FACSLyric ${ }^{\mathrm{TM}}$. Data were analyzed with the use of Kaluza software (version 2.1).

Statistical analysis. Statistical data (absolute counts and percentages of gated cells within the quadrants) obtained from Kaluza software were copied into spreadsheets. Descriptive statistics, medians, and ranges were calculated using Statistica version 13.1 (StatSoft).

\section{Results}

\section{One positive marker (CD25) and one negative selection marker (CD127 or CD26 or CD6) enable comparable initial gating}

As the first step, we gated potential Tregs using combinations of one positive marker $\mathrm{CD} 25^{+}$and one of the tested negative markers, CD26 $6^{\text {low } /}$ or $\mathrm{CD} 127^{\text {low/ }}$ or $\mathrm{CD} 6^{\text {low/ }}$, within the $\mathrm{CD} 45^{+} \mathrm{CD} 3{ }^{+} \mathrm{CD} 4^{+}$ cells (Fig. 1A). The median percentage of gated cells was $5.6 \%$ (range $2.7-11 \%$ ). The level of expression of FoxP3 and CD39 was used to test different initial gating strategies. The rates of $\mathrm{FoxP}^{+}$and/ /or CD $39^{+}$cells were $80.8 \%, 87.5 \%$ and $85.2 \%$ in gates $\mathrm{CD} 127^{\text {low/ }}, \mathrm{CD} 26^{\text {low/ }}$ and $\mathrm{CD} 6^{\text {low/ }}$, respectively (Fig. 1B). The differences were not significant. Therefore, we decided to use a backbone panel based on the expression of CD25 and CD127, which has been already validated and approved in many laboratories.

\section{Almost overlapping high fluorescence intensity of FoxP3 and CD39 within the subpopulation CD45RA'}

In the next analysis, we compared the fluorescence intensities of FoxP3 and CD39 within the gated potential Tregs with the positive or negative expression of CD45RA. Treg gating was based on the three tested initial gating strategies described above. We found a high percentage of $\mathrm{FoxP}^{+}(50.3 \%$; range 34.2$57.4 \%)$ and $\mathrm{CD}^{3} 9^{+}$cells $(53.1 \%$; range $45.9-58.9 \%)$ within gated CD45RA cells. A low percentage of $\mathrm{CD}_{45 \mathrm{RA}^{+}}$cells demonstrated the expression of FoxP3 or CD39 (3\%; range 0.3-10.6\%). The rates differed depending on the gating strategy but the differences were not statistically significant (data not shown graphically). This finding was additional proof that a panel based on the expression of CD25 and CD127 was a suitable backbone for further tests. 


\section{The CD26 ${ }^{\text {int/high }}$ population is more suitable than the CD6 $6^{\text {int/high }}$ population for the exclusion of contamination with Tcons}

As the next step, we performed a comparison of additional membrane staining with anti-CD26 and anti-CD6 antibodies to eliminate cells with the CD26 $6^{\text {inthigh }}$ or $\mathrm{CD} 6^{\text {int/high }}$ phenotype, representing the Tcons, from the final enumeration. The CD26 int/high population appeared to be more evident to exclude undesired cells than the $\mathrm{CD} 6^{\text {int/high }}$ population owing to a clear cut-off of Tcons from the final count. Moreover, the percentage of FoxP3-CD39- cells was higher (26\% vs. $16 \%$ ) in gating based on CD26 membrane expression suggesting more adequate elimination of Tcons. The graphical presentation of this comparative gating is presented in Figure 2.

\section{CD39 is a valuable marker to replace FoxP3}

In most analyses, we compared the expression of CD39 with FoxP3. Among the gated highly suppressive cells $\left(\mathrm{CD} 25^{+} \mathrm{CD} 127^{\text {low/ }}-\mathrm{CD} 26^{\text {low/ }} \mathrm{CD} 45 \mathrm{RA}^{-}\right)$expressing $\mathrm{CD}^{3} 9^{+}, 90.9 \%$ were also FoxP3 ${ }^{+}$. Moreover, $92.3 \%$ of the cells were either $\mathrm{CD}_{3} 9^{+}$or $\mathrm{FoxP}^{+}$. In contrast, $\mathrm{CD} 45 \mathrm{RA}^{+}$cells were a small subset within the gated $\mathrm{CD} 25^{+} \mathrm{CD} 127^{\text {low/ }} \mathrm{CD} 26^{\text {low/ }}$ cells characterized by low expression of FoxP $3^{+}$and/or CD39. One example of the histograms is presented in Figure 3.

\section{CD31 is a valuable marker of thymus-derived Tregs (tTregs)}

The next step was to define the origin of Tregs by the membrane expression of $\mathrm{CD} 1^{+}$(tTregs $v s$. peripheral Tregs with extrathymic origin; pTregs) and to check the state of activation.

A higher number of $\mathrm{CD} 31^{+}$Tregs was detected within the compartment of the naïve immunophenotype identified by the positive expression of antigen CD45RA. Among the naïve CD45RA ${ }^{+}$Tregs, CD $31^{+}$ cells were predominantly represented by a subgroup lacking the expression of CD39 (median 39.1\%). $\mathrm{CD} 31^{+} \mathrm{CD} 39^{+}$cells were detected in $1.4 \%$ of gated CD45RA ${ }^{+}$Tregs. However, the median rates of $\mathrm{CD}_{31}{ }^{+} \mathrm{CD} 39^{-}$and $\mathrm{CD} 31^{+} \mathrm{CD} 39^{+}$within the CD45RA cells were comparable: 9.2 and $8.7 \%$, respectively.

The expression of the activation marker CD71 was weak in unstimulated lymphocytes. Therefore, we decided to proceed with HLA-DR (the late activation marker) staining. This staining was more apparent within the effector CD45RA- Tregs. Among CD $4{ }^{+} \mathrm{CD} 25^{+} \mathrm{CD} 127^{\text {low/ }} \mathrm{CD} 45 \mathrm{RA}-\mathrm{HLA}-\mathrm{DR}{ }^{+}$effector Tregs, $95 \%$ were $\mathrm{CD} 39^{+}$cells and none were $\mathrm{CD} 31^{+}$ cells, in contrast to naïve $\mathrm{CD} 4{ }^{+} \mathrm{CD} 25^{\text {int/high }} \mathrm{CD}$ $127^{\text {low } /}$ CD $45 \mathrm{RA}^{+}$Tregs, which were all HLA-DR negative, with $95 \%$ of cells being CD39- and $41 \%$ being $\mathrm{CD} 31^{+}$. The graphical presentation is shown in Figure 4. Anti-HLA-DR staining was used to check the activation status of gated Treg subsets but was not used for the final enumeration panel to simplify the analysis.

\section{Gating strategy to enumerate circulating Tregs}

Using a gating strategy based on lymphocytes, $\mathrm{CD} 25^{+} \mathrm{CD} 127^{\text {low/- }}$ versus $\mathrm{CD} 25^{+} \mathrm{CD} 26^{\text {low/- }}$, we captured a similar number of cells within $\mathrm{CD} 45^{+} \mathrm{CD}^{+} \mathrm{CD}^{+}$ cells: $5.4 \%$ (range $3.2-10.7 \%$ ) and $5.6 \%$ (range $3.1-11 \%$ ), respectively. Moreover, the numbers of cells that were CD45RA ${ }^{+}, \mathrm{CD}_{4} 4 \mathrm{RA}^{-}, \mathrm{CD} 39^{+}$and $\mathrm{CD} 31^{+}$within the gated population were comparable. However, the final strategy to count the whole compartment of Tregs uses the CD26 $6^{\text {low/- }}$ population within $\mathrm{CD} 25^{+} \mathrm{CD} 127^{\text {low } /}$, from the gated $\mathrm{CD} 45^{+} \mathrm{CD} 3{ }^{+} \mathrm{CD} 4{ }^{+}$ cells, to exclude accidental contamination with activated Tcons more precisely. Lymphocytes are gated on a CD45/SS dot plot, then $\mathrm{CD}^{+} \mathrm{T}$ cells $\left(\mathrm{CD}^{+}{ }^{+} \mathrm{CD} 4{ }^{+}\right.$cells) are gated on a $\mathrm{CD} 3 / \mathrm{CD} 4$ dot plot. Tregs are initially identified as $\mathrm{CD} 25^{+} \mathrm{CD} 127^{\text {low/ }}$ on a CD25/CD127 dot plot. The next step is to exclude cells with intermediate or high expression of CD26 that is very obvious on a CD45RA/CD26 dot plot (among $\mathrm{CD} 25^{+} \mathrm{CD} 127^{\mathrm{low} /}$ ). The cells detected after the elimination of $\mathrm{CD} 26^{+}$cells are taken to calculate the total number of Tregs. This gate is also a first step to identify different Treg subsets: two quadratic gates should be placed to discriminate effector/memory (CD45RA-CD26 $\left.6^{\text {low/ } /}\right)$ and naïve Treg $\left(C D 45 \mathrm{RA}^{+} \mathrm{CD}-\right.$ $26^{\text {low-} /}$ ) cells on a CD45RA/CD26 dot plot. The next step to better characterize Treg subsets is to check CD31 and CD39 expression within these two gates. The graphical presentation of the gating strategy for the enumeration panel is presented in Figure 5.

The presented rates of total Tregs and Treg subsets were calculated from $\mathrm{CD} 4^{+} \mathrm{T}$ cells. The numbers of total Tregs and Treg subsets are expressed as the percentage of the lymphocyte gate from the CD45/SS cytogram. Absolute values were calculated by multiplying these percentages by the number of lymphocytes in a microliter of blood, determined on a hematology analyzer.

With the use of our gating protocol, the median absolute count was 66.4 (range 22.8-162.7) cells $/ \mu 1$. The median rate within $\mathrm{CD}^{+}$and the median absolute count of Tregs expressing CD39 was $2.4 \%$ (range $1-8.7 \%)$ and $18.5(1.7-84.5)$ cells $/ \mu 1$, respectively.

A trial analysis of the panel performed in 10 patients with a moderate or severe form of chronic GVHD (cGVHD) showed a lower median percentage within $\mathrm{CD}^{+}$cells and absolute values of Tregs: $5.1 \%$ (range 2.1-15.8\%) and 33.6 (range 15.3-91.5) cells $/ \mu \mathrm{l}$, 


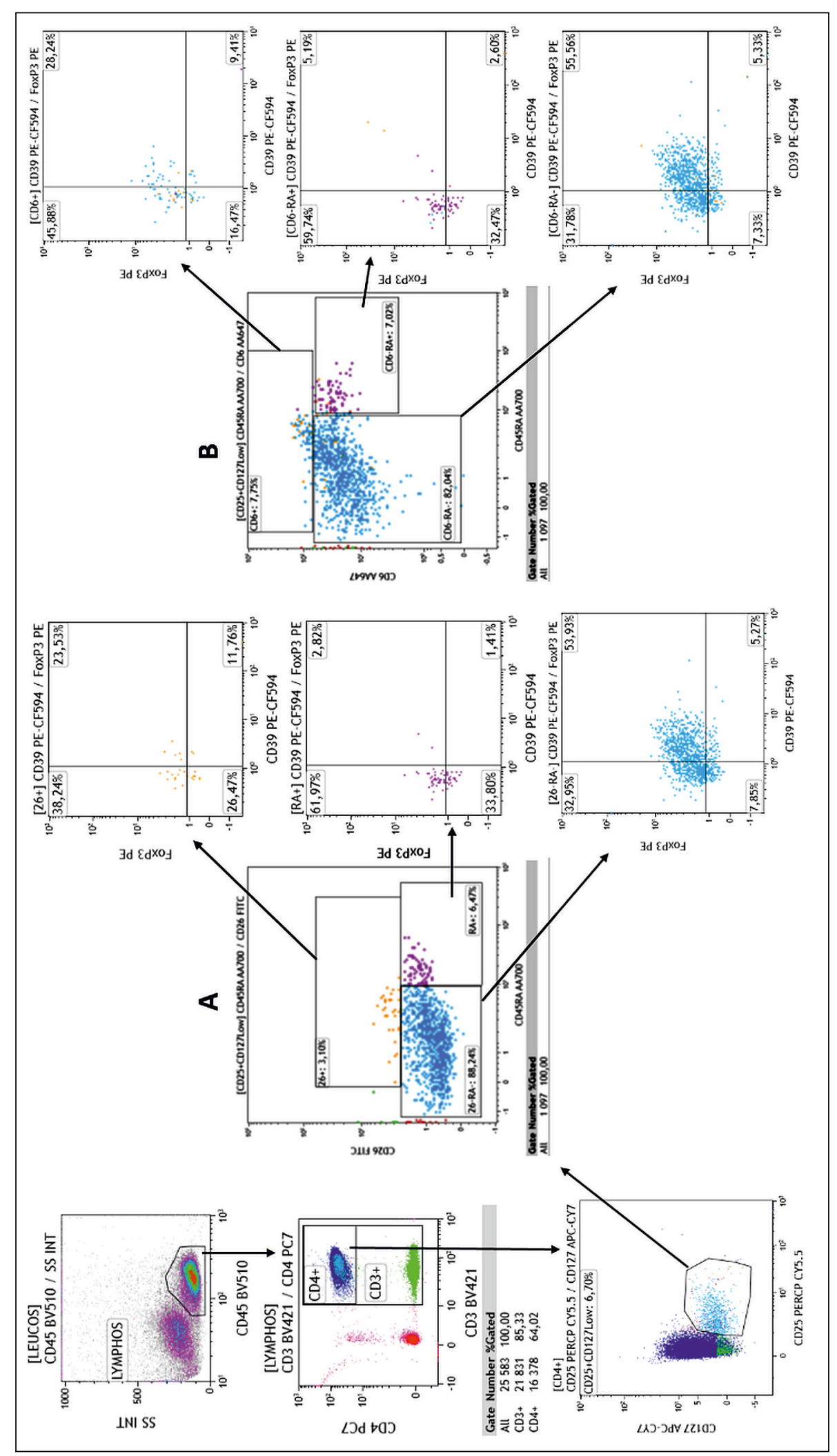

Figure 2. Comparison of two gating strategies based on the exclusion of CD26 $6^{+}$or $\mathrm{CD}^{+} \mathrm{T}$-cells from the final Treg enumeration protocol. Lymphocytes are gated on a CD45/SS dot plot, then $\mathrm{CD}^{+} \mathrm{T}$ cells $\left(\mathrm{CD} 3{ }^{+} \mathrm{CD} 4{ }^{+}\right.$cells) are gated on a CD3/CD4 dot plot. Tregs are initially identified as $\mathrm{CD} 25^{+} \mathrm{CD} 127^{\text {low/ }}$ on a CD25/CD127 dot plot. The next step is to exclude cells with intermediate or high expression of CD26(A) on a CD45RA/CD26 dot plot (among CD25 ${ }^{+} \mathrm{CD} 127^{\text {low/- }}$ ) or with intermediate or high expression of CD6 (B) on a CD45RA/CD6 dot plot (among CD25+CD127 low/-). The three quadratic gates represent the following: the upper gate includes Tcons by either high/intermediate expression of CD26 or CD6; the lower left includes memory/effector Tregs; and the lower right includes naïve Tregs. The comparative expression of CD31 and CD39 within_these quadratic gates of two gating protocols is also provided. 


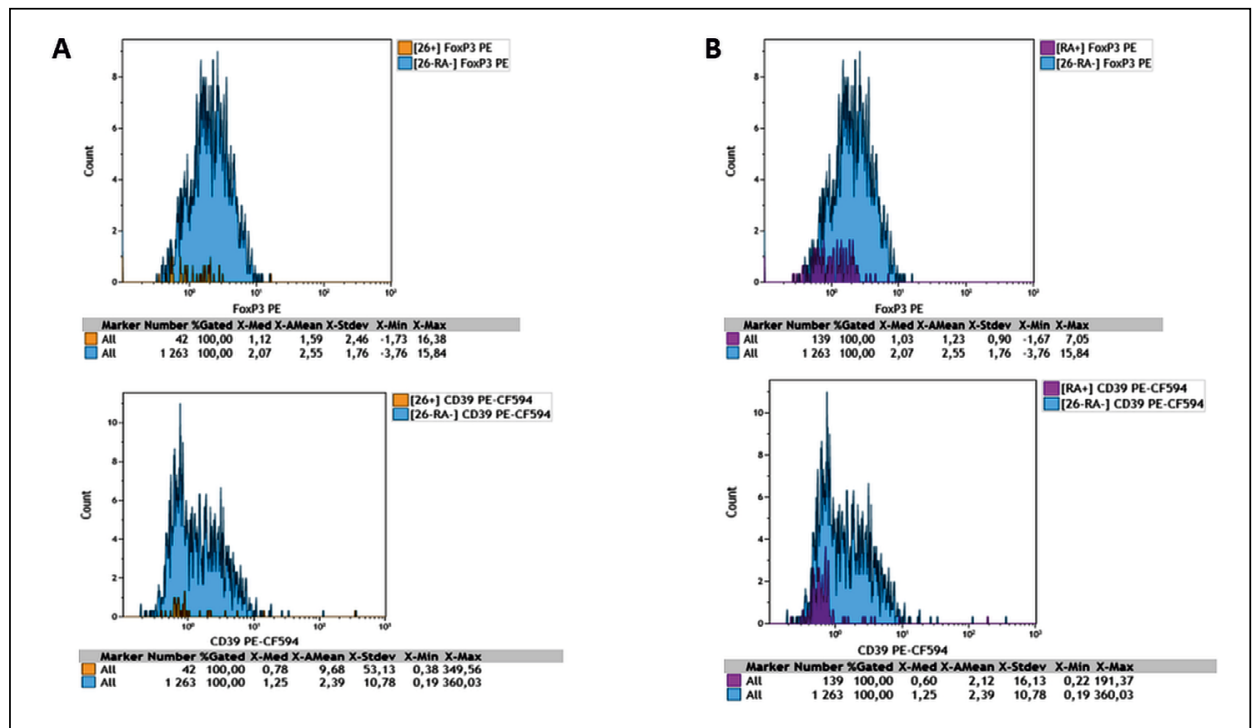

Figure 3. Comparison of FoxP3 and CD39 expression. A. Histograms showing comparable count of cells expressing FoxP3 and CD39 within a compartment of CD25 ${ }^{+} \mathrm{CD} 127^{\text {low/ }} \mathrm{CD} 26^{\text {low/ }} \mathrm{CD} 45 \mathrm{RA}-(26-\mathrm{RA}-)$ Tregs with a compartment of CD25 ${ }^{+} \mathrm{C}-$ D127 low/ $C D 26^{\text {int/high }} \mathrm{CD} 45 \mathrm{RA}^{+}(26+)$ T cons; B. Histograms showing comparable count of cells expressing FoxP3 and CD39 within a compartment of $\mathrm{CD} 25^{+} \mathrm{CD} 127^{\text {low/- }} \mathrm{CD} 26^{\text {low/ }} \mathrm{CD} 45 \mathrm{RA}-(26-\mathrm{RA}-)$ cells (memory/effector Tregs) with a compartment of $\mathrm{CD} 25^{+} \mathrm{CD} 127^{\text {low } /-C D} 26^{\text {low } /-C D} 45 \mathrm{RA}^{+}(\mathrm{RA}+)$ cells (naïve Tregs).

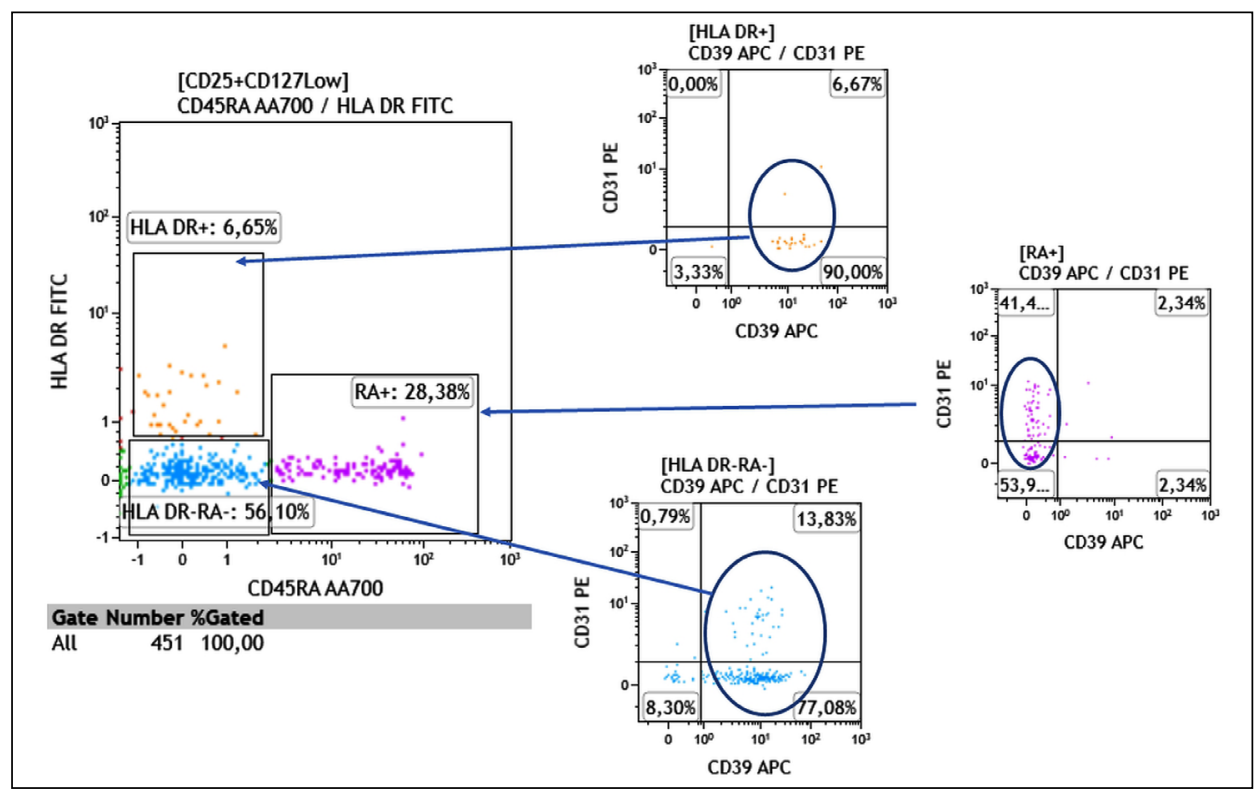

Figure 4. Expression of HLA-DR (the late activation marker) on Treg subsets. A left CD45RA/HLA-DR dot plot represents Tregs subsets gated from lymphocytes by the $\mathrm{CD} 3{ }^{+} \mathrm{CD} 4^{+} \mathrm{CD} 25^{+} \mathrm{CD} 127^{\text {low/- }}$ immunophenotype. The three dot plots on the right present a comparison of CD31 and CD39 expression among naïve Tregs (CD45RA ${ }^{+} \mathrm{HLA}^{-D R}$ ) and among effector/ /memory Tregs (CD45RA) with a positive late activation marker (HLA-DR ${ }^{+}$) and with negative HLA-DR expression.

respectively. Differences between volunteers and the GVHD patients were especially visible in absolute values of Treg subsets. The summarized results for Tregs in healthy donors and patients with chronic GVHD are presented in Table 1.

\section{Discussion}

Tregs are a small subset of $\mathrm{CD} 4^{+} \mathrm{T}$ lymphocytes but they play a crucial role in maintaining the balance of the immune system. In transplant medicine, Tregs 


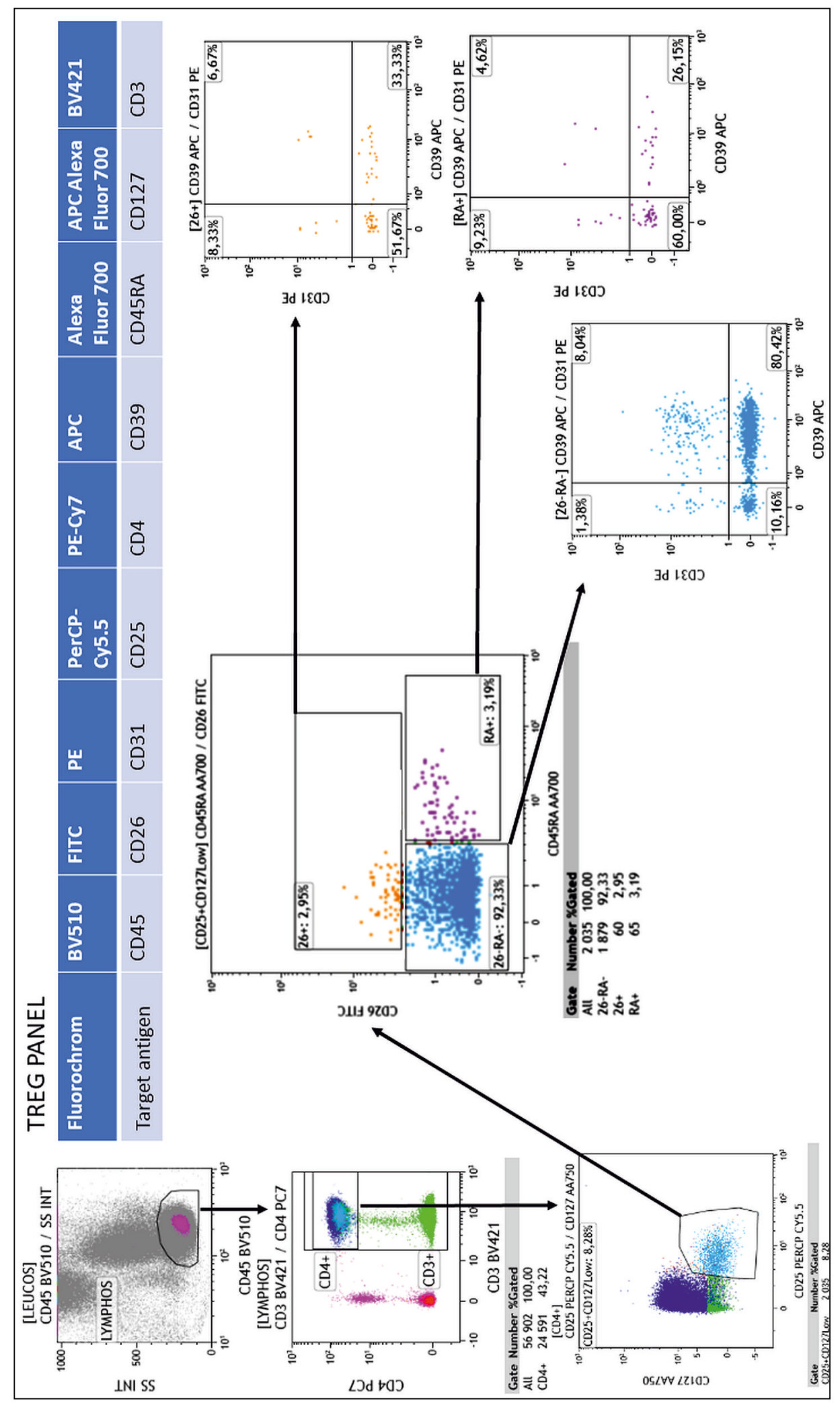

Figure 5. The enumeration panel and the final gating strategy. Lymphocytes are gated on a CD45/SS dot plot, then CD4 ${ }^{+}$ $\mathrm{T}$ cells $\left(\mathrm{CD} 3{ }^{+} \mathrm{CD} 4{ }^{+}\right.$cells) are gated on a CD3/CD4 dot plot. Tregs are initially identified as $\mathrm{CD} 25^{+} \mathrm{CD} 127^{\text {low/- }}$ on a CD25/ /CD127 dot plot. The next step is to exclude cells with intermediate or high expression of CD26 on a CD45RA/CD26 dot plot (among CD $25^{+} \mathrm{CD} 127^{\text {low } /-}$ ). The cells detected after the elimination of CD $26^{+}$cells are taken to obtain the total number of Tregs. In the CD45RA/CD26 dot plot, the lower two quadratic gates are placed to discriminate effector/memory $\left(\mathrm{CD} 45 \mathrm{RA}^{-} \mathrm{CD} 26^{\text {low/ } /}\right)$ and naïve Tregs $\left(\mathrm{CD}^{2} 5 \mathrm{RA}^{+} \mathrm{CD} 26^{\text {low/ }}\right)$. The next step to characterize Treg subsets is to check $\mathrm{CD} 31$ and CD39 expression within these two gates. 
Table 1. Comparison of percentages and absolute values of Tregs in healthy donors and patients with chronic GVHD

\begin{tabular}{|c|c|c|c|c|c|}
\hline T regulatory cells & $\begin{array}{l}\text { Phenotype within } \\
\text { CD45 }^{+} \text {CD3 }^{+} \text {CD4 }^{+}\end{array}$ & $\begin{array}{l}\text { Healthy donors } \\
\text { Median (range) }\end{array}$ & $\begin{array}{l}\text { Patients with cGVHD } \\
\text { Median (range) }\end{array}$ & Normal range & Units \\
\hline Total & $\begin{array}{l}\mathrm{CD25}^{+} \mathrm{CD}^{-27} 7^{- \text {llow }} \\
\text { CD26 }^{\text {-low }}\end{array}$ & $\begin{array}{c}5.4(3.2-10.7) \\
66.4(22.8-162.7)\end{array}$ & $\begin{array}{c}5.1(2.1-15.8) \\
33.6(15.3-91.5)\end{array}$ & $\begin{array}{c}4-10.7 \\
20-126.3\end{array}$ & $\begin{array}{c}\%(\text { in } \mathrm{CD} 4+) \\
\text { cells } / \mu \mathrm{l}\end{array}$ \\
\hline $\begin{array}{l}\text { Effector/ } \\
\text { /Memory }\end{array}$ & $\begin{array}{l}\text { CD25 } 5^{+} \mathrm{CD} 127^{- \text {-low }} \\
\text { CD26 } \\
\text {-low } \\
\text { CD45RA }\end{array}$ & $\begin{array}{l}3.8(1.3-10.3) \\
43(15.6-81.4)\end{array}$ & $\begin{array}{l}4.6(2.1-14.7) \\
25.8(15-63.6)\end{array}$ & $\begin{array}{c}2.4-8.7 \\
14.3-88.3\end{array}$ & $\begin{array}{c}\%(\text { in } \mathrm{CD} 4+) \\
\text { cells } / \mu 1\end{array}$ \\
\hline Naïve & $\begin{array}{l}\mathrm{CD} 25^{+} \mathrm{CD} 127^{- \text {llow }} \\
\text { CD26- } \\
\text {-low } \\
\text { CD45RA }^{+}\end{array}$ & $\begin{array}{c}1.4(0.4-5.0) \\
16.9(2.2-103.5)\end{array}$ & $\begin{array}{l}0.8(0.04-2.0) \\
4.4(0.2-28.0)\end{array}$ & $\begin{array}{c}0.4-4.5 \\
2.3-54.0\end{array}$ & $\begin{array}{c}\%(\text { in } \mathrm{CD} 4+) \\
\text { cells } / \mu 1\end{array}$ \\
\hline Highly suppressive & $\begin{array}{l}\mathrm{CD} 25^{+} \mathrm{CD} 127^{- \text {-low }} \\
\mathrm{CD} 26^{\text {-low }} \mathbf{C D 3 9}^{+}\end{array}$ & $\begin{array}{c}2.4(1-8.7) \\
18.5(1.7-84.5)\end{array}$ & $\begin{array}{c}2.7(0.8-4.7) \\
15.7(7.3-45.2)\end{array}$ & & $\begin{array}{c}\%(\text { in } \mathrm{CD} 4+) \\
\text { cells } / \mu \mathrm{l}\end{array}$ \\
\hline Thymus emigrants & $\begin{array}{l}\mathrm{CD} 25^{+} \mathrm{CD} 127^{- \text {-low }} \\
\mathrm{CD} 26^{\text {-llow }} \mathbf{C D 3 1}^{+}\end{array}$ & $\begin{array}{l}1.5(0.8-4.2) \\
16.3(4.6-88)\end{array}$ & $\begin{array}{c}1.4(0.3-4.2) \\
8.6(1.2-29.5)\end{array}$ & & $\begin{array}{c}\%(\text { in } \mathrm{CD} 4+) \\
\text { cells } / \mu \mathrm{l}\end{array}$ \\
\hline
\end{tabular}

are responsible for the induction of the immunotolerance that preserves the transplanted organ or tissue. This T-cell subset prevents GVHD development after HCT [1, 30]. The identification of Tregs is beneficial for clinical purposes, e.g., to monitor immune responses to immunomodulating therapies after HCT, to isolate and to sort viable regulatory cells for tolerance-inducing therapies or to eliminate tumor-infiltrating Tregs and activate anti-tumor immune responses. A growing need to find a reliable and accurate method to identify a Treg compartment inspired us to design a simple protocol that could be used in flow cytometry laboratories as a routine analytical procedure [13].

Tregs in humans are heterogeneous in both immunophenotype and function. They consist of subsets of highly suppressive, terminally differentiated effector or activated Tregs and naïve or resting Tregs with hidden suppressive potential $[22,31]$. This population is also diversified according to its origin into natural tTregs and induced Tregs that differentiate upon exposure to an antigen under tolerogenic conditions in peripheral tissues (pTregs) [32-34]. There are also Tcons deprived of suppressive activity that secrete pro-inflammatory cytokines but, upon activation, they are able transiently to upregulate FoxP3 [17]. The nuclear localization of FoxP3 makes the permeabilization of cellular and nuclear membranes necessary for FoxP3 detection, and this may lead to inaccurate enumeration due to cell loss and the omission of cells with low FoxP3 fluorescence intensity [14]. During the last decade, several Treg-associated membrane markers have been identified, and their ability to isolate functional Tregs has been tested primarily in the context of cell sorting. Following these studies, some of the well-known surface antigens were chosen and tested by us in various combinations.
The CD25 antigen (alpha-chain for the interleukin (IL)-2 receptor) is a primary cell-surface marker for Tregs, but its high expression on $\mathrm{CD}^{+}{ }^{+}$cells means that it cannot be used as the sole criterion to capture Tregs because even a pure $\mathrm{CD} 4{ }^{+} \mathrm{CD} 25^{\text {high }}$ population contains substantial contamination with proinflammatory $T$ cells $[35,36]$. Therefore, additional selective markers are needed. Tregs exhibit consistently low expression of CD127 alpha chain for the IL-7 receptor. The low/negative expression of CD127 antigen has been tested in combination with CD4 and CD25, showing high levels of FoxP3 and a strong correlation with $\mathrm{T}$ cells expressing $\mathrm{CD} 4{ }^{+} \mathrm{CD} 25^{+} \mathrm{FoxP}^{+}[16,20$, 24]. Moreover, $\mathrm{CD} 4{ }^{+} \mathrm{CD} 25^{+} \mathrm{CD} 127^{\text {low/ }}$ cells expressing a low level of FoxP3 remain strongly suppressive [19]. Similarly, the low/negative CD6 expression is indicated to be another Treg-associated marker. Cells sorted by the $\mathrm{CD} 4^{+} \mathrm{CD} 25^{\text {high }} \mathrm{CD} 127^{\text {low/ }} \mathrm{CD} 6^{\text {low/ } / \text { immu- }}$ nophenotype showed high enrichment of FoxP3+ cells and high in vitro suppression activity [26]. The use of CD6 as a negative Treg marker was tested in our study in comparison with CD26 and gave comparable results. However, for the sake of simplicity, in the final enumeration strategy, the elimination of $\mathrm{CD} 26^{+}$cells appeared to be more apparent than that of $\mathrm{CD}^{+}$cells. In turn, the CD26 antigen is an extracellular peptidase that is upregulated in $\mathrm{CD}^{+}$ effector T cells, in contrast to CD127, which is not upregulated upon activation [27]. Following this path, because negative/low CD26 expression enables distinction between activated Tcons and Tregs, CD26 was chosen for the final gating strategy. Another tested marker, the CD39 antigen, is ectonucleoside triphosphate diphosphohydrolase 1 , which hydrolyzes extracellular ATP and ADP to AMP. CD39 is presented in the literature as defining a Treg subset with a frequency and expression level that correlate 
with those of FoxP3 in $\mathrm{CD}^{+}{ }^{+} \mathrm{T}$ cells [25]. A comparison performed in our analyses confirmed the almost overlapping expression of FoxP3 and CD39 in cells selected by other cell-surface Treg-associated markers.

We found high expression of FoxP3 and CD39 within the CD45RA- subpopulation and low expression within the CD45RA ${ }^{+}$subpopulation, which is in agreement with data from the literature [22]. However, low expression of suppressive markers FoxP3 and CD39 did not deprive a naïve CD45RA ${ }^{+}$subset of the Treg compartment in our study. It was demonstrated that $\mathrm{CD} 4{ }^{+} \mathrm{CD} 127^{\text {low } /-} \mathrm{CD} 25^{+} \mathrm{CD} 45 \mathrm{RA}^{+}$cells have a stable TSDR (T-cell specific demethylation region) demethylated phenotype [22, 31]. Naïve Tregs express CD127 antigen at reduced levels and CD25 antigen at lower levels than memory Tregs express, which is why cells with intermediate expression of CD25 and low expression of CD127 were captured in our analyses [37].

Taking into account the expression of CD31 antigen, we intended to identify a Treg subpopulation that is especially interesting in the HCT setting. CD31 (platelet endothelial cell adhesion molecule; PECAM-1) was included as a marker to identify $\mathrm{CD}^{+}{ }^{+}$recent thymus emigrants (RTEs) that may persist in circulation expressing CD31. In a study by Douaisi et al., most egress-capable mature $\mathrm{CD}_{4} \mathrm{RA}^{+}$single-positive (SP) $\mathrm{CD}^{+}$thymocytes express CD31; however, FoxP3-expressing cells in the thymus are overrepresented within the CD31semimature CD45RACD4 SP subset displaying enhanced levels of activation markers, while among mature $\mathrm{CD} 45 \mathrm{RA}^{+} \mathrm{CD} 4 \mathrm{SP}$ thymocytes, the frequency of the FoxP3 ${ }^{+}$cells is similar in $\mathrm{CD} 31^{-}$and $\mathrm{CD} 31^{+}$ subsets [28]. It is hypothesized that CD31- semimature CD45RA-CD4 SP thymocytes re-express CD31 upon the completion of their maturation and the acquisition of CD45RA, egressing from the thymus as RTEs. However, it cannot be excluded that a subset of $\mathrm{CD} 31 \mathrm{CD}^{-} 45 \mathrm{RA}^{+} \mathrm{CD} 4^{+}$thymocytes can egress from the thymus and become difficult to distinguish from the naïve peripheral $\mathrm{CD} 31^{-} \mathrm{CD} 4^{+}$ $\mathrm{T}$ cells. Generally, the expression of CD31 is downregulated upon $\mathrm{T}$-cell receptor activation and cell division. To distinguish highly suppressive Tregs (effector/memory Tregs) from naïve or resting cells with suppressive potential, we used the membrane markers CD45RA, CD31, and CD39. Within cells with the naïve immunophenotype CD45RA ${ }^{+}$(basically CD39-HLA-DR') we could identify CD31+ tTregs that are RTEs and CD31- that would be extrathymic pTregs, but according to the data cited above, the thymic origin cannot be excluded. In turn, within $\mathrm{CD} 4{ }^{+} \mathrm{CD} 25^{+} \mathrm{CD} 127^{\text {low/- }} \mathrm{CD} 26^{\text {low/- }}$ cells, we identified effector highly suppressive Tregs defined as having the CD45RA-CD31-CD39+ immunophenotype, and activated tTregs after the transition to CD45RA-CD $31^{+} \mathrm{CD} 39^{+}$effector cells, while cells with the CD45RA-CD31-CD39-phenotype could be a memory resting pool of pTregs or tTregs with a transiently downregulated suppressive marker. A deeper insight into the Treg subpopulation is especially exciting for transplantation physicians because highly activated $\mathrm{CD} 45 \mathrm{RA}^{-} \mathrm{CD} 39^{+} \mathrm{FoxP}^{+}$Tregs traffic into tissues involved in cGVHD-related processes, where they play a suppressive function while naïve $\mathrm{CD}_{45 \mathrm{RA}^{+}}$Tregs control cGVHD effectors [38]. Another interesting issue refers to a hypothesis that the maintenance of the naïve Treg compartment may be predominantly thymic-independent, with a strong role of IL-7 dependent signaling [39]. Clinical improvement following ECP or other Treg-enhancing immunomodulatory therapies in patients with GVHD supports this thesis. There are data showing that clinical amelioration correlates with increasing levels of Tregs, despite the debilitating alloimmune processes involving the thymus that occur in the course of GVHD [6-8, 12]. On a laboratory basis, shifts within the $\mathrm{CD}^{+}$and Treg compartments could be efficiently evaluated with the use of our protocol in patients suffering from cGVHD who undergo immunomodulatory treatment. Eight of the 10 patients had been treated with ECP for more than 1 year, with partial remission of skin manifestations of GVHD at the time of our Treg analyses. Their results vary, but the median values are generally lower when compared with those of healthy volunteers, especially the naïve Tregs compartment. However, further tests in patients with cGVHD are required to record the shifts of Treg subsets upon treatment on the timeline.

The final results of Treg enumeration were presented as both a percentage of $\mathrm{CD} 4^{+}$cells and an absolute count per microliter in whole blood. The literature suggests that it is essential to provide both values to show real differences [13]. After HCT, the Treg/CD4 ratio is reported to be altered in patients with severe GVHD and in cases of relapse, while the reconstitution of Tregs achieves the highest absolute numbers in patients without GVHD [40].

In summary, the final panel we propose gives the possibility of obtaining reproducible and comparable results when capturing an entire Treg compartment in whole blood. Moreover, it enables insight into Treg subsets. With the use of the additional cell-surface markers CD45RA and CD31, the panel gives additional information about the functionality, maturity and origin of Tregs. 


\section{Financial support}

The project was supported by the French Government and the French Embassy in Poland (science.varsovie-amba@diplomatie.gouv.fr) and was conducted thanks to a French Scholarship in Laboratoire de Génétique des Hémopathies IUCT Oncopole, Toulouse (CAMPUS FRANCE file no 907783J).

\section{Special acknowledgments}

To the Team of the Laboratoire de Génétique des Hémopathies IUCT Oncopole Toulouse for enormous support.

\section{Authorship statement}

AP - study concept and design, data analysis and interpretation, and writing the paper; MP - data analysis and interpretation, participation in drafting the text, and critical revision; MT and MK - data analysis and critical revision; KL - data analysis and interpretation, participation in drafting the text, and critical revision; FV — study supervision, data interpretation, and critical revision. All authors accepted the final content of the manuscript.

\section{Conflict of interest}

The authors declare no conflict of interest.

\section{References}

1. Trenado A, Charlotte F, Fisson S, et al. Recipient-type specific $\mathrm{CD} 4+\mathrm{CD} 25+$ regulatory $\mathrm{T}$ cells favor immune reconstitution and control graft-versus-host disease while maintaining graft-versus-leukemia. J Clin Invest. 2003; 112(11): 16881696, doi: 10.1172/JCI17702, indexed in Pubmed: 14660744.

2. Sakaguchi S, Yamaguchi T, Nomura T, et al. Regulatory T cells and immune tolerance. Cell. 2008; 133(5): 775-787, doi: 10.1016/j.cell.2008.05.009, indexed in Pubmed: 18510923.

3. Couriel DR, Hosing C, Saliba R, et al. Extracorporeal photochemotherapy for the treatment of steroid-resistant chronic GVHD. Blood. 2006; 107(8): 3074-3080, doi: 10.1182/ blood-2005-09-3907, indexed in Pubmed: 16368882.

4. Gorgun G, Miller KB, Foss FM, et al. Extracorporeal photopheresis in chronic graft-versus-host disease. Bone Marrow Transplant. 2002; 29(9): 719-725, doi: 10.1038/sj.bmt.1703529, indexed in Pubmed: 12040467.

5. Rubegni P, Sbano P, Cevenini G, et al. CD4+CD25+ lymphocyte subsets in chronic graft versus host disease patients undergoing extracorporeal photochemotherapy. Int J Immunopathol Pharmacol. 2007; 20(4): 801-807, doi: 10.1177/039463200702000416, indexed in Pubmed: 18179753.

6. Biagi E, Di Biaso I, Leoni V, et al. Extracorporeal photochemotherapy is accompanied by increasing levels of circulating CD4+CD25+GITR + Foxp3 + CD62L + functional regulatory $\mathrm{T}$-cells in patients with graft-versus-host disease. Transplantation. 2007; 84(1): 31-39, doi: 10.1097/01. tp.0000267785.52567.9c, indexed in Pubmed: 17627234.

7. Schmitt S, Johnson TS, Karakhanova S, et al. Extracorporeal photophoresis augments function of CD4+CD25+FoxP3+ regulatory $\mathrm{T}$ cells by triggering adenosine production. Transplantation. 2009; 88(3): 411-416, doi: 10.1097/TP.0b013e3181aed927, indexed in Pubmed: 19667946.
8. Gao W, Lu Y, El Essawy B, et al. Contrasting effects of cyclosporine and rapamycin in de novo generation of alloantigen-specific regulatory T cells. Am J Transplant. 2007; 7(7): 1722-1732, doi: 10.1111/j.1600-6143.2007.01842.x, indexed in Pubmed: 17511761.

9. Jedlickova Z, Burlakova I, Bug G, et al. Therapy of sclerodermatous chronic graft-versus-host disease with mammalian target of rapamycin inhibitors. Biol Blood Marrow Transplant. 2011; 17(5): 657-663, doi: 10.1016/j.bbmt.2010.07.025, indexed in Pubmed: 20696263.

10. Teshima T. JAK inhibitors: a home run for GVHD patients? Blood. 2014; 123(24): 3691-3693, doi: 10.1182/ blood-2014-04-570325, indexed in Pubmed: 24926071.

11. Zeiser R, Nguyen VuH, Beilhack A, et al. Inhibition of $\mathrm{CD} 4+\mathrm{CD} 25+$ regulatory $\mathrm{T}$-cell function by calcineurin-dependent interleukin-2 production. Blood. 2006; 108(1): 390399, doi: 10.1182/blood-2006-01-0329, indexed in Pubmed: 16522809

12. Di Biaso I, Di Maio L, Bugarin C, et al. Regulatory T cells and extracorporeal photochemotherapy: correlation with clinical response and decreased frequency of proinflammatory $\mathrm{T}$ cells. Transplantation. 2009; 87(9): 1422-1425, doi: 10.1097/ TP.0b013e3181a27a5d, indexed in Pubmed: 19424046.

13. Hardy MY, Vari F, Rossetti T, et al. A flow cytometry based assay for the enumeration of regulatory T cells in whole blood. J Immunol Methods. 2013; 390(1-2): 121-126, doi: 10.1016/j. jim.2012.07.004, indexed in Pubmed: 22824721.

14. Fazekas de St Groth B, Zhu E, Asad S, et al. Flow cytometric detection of human regulatory T cells. Methods Mol Biol. 2011; 707: 263-279, doi: 10.1007/978-1-61737-979-6_17, indexed in Pubmed: 21287341.

15. Pitoiset F, Barbié M, Monneret G, et al. A standardized flow cytometry procedure for the monitoring of regulatory $\mathrm{T}$ cells in clinical trials. Cytometry B Clin Cytom. 2018; 94(5): 621626, doi: 10.1002/cyto.b.21622, indexed in Pubmed: 29316248.

16. Pitoiset F, Cassard L, El Soufi K, et al. Deep phenotyping of immune cell populations by optimized and standardized flow cytometry analyses. Cytometry A. 2018; 93(8): 793-802, doi: 10.1002/cyto.a.23570, indexed in Pubmed: 30168890.

17. d'Hennezel E, Piccirillo CA. Analysis of human FOXP3+ Treg cells phenotype and function. Methods Mol Biol. 2011; 707: 199-218, doi: 10.1007/978-1-61737-979-6_13, indexed in Pubmed: 21287337.

18. Seddiki N, Santner-Nanan B, Martinson J, et al. Expression of interleukin (IL)-2 and IL-7 receptors discriminates between human regulatory and activated T cells. J Exp Med. 2006; 203(7): 1693-1700, doi: 10.1084/jem.20060468, indexed in Pubmed: 16818676.

19. Klein S, Kretz CC, Krammer PH, et al. CD127(low/-) and FoxP3(+) expression levels characterize different regulatory T-cell populations in human peripheral blood. J Invest Dermatol. 2010; 130(2): 492-499, doi: 10.1038/jid.2009.313, indexed in Pubmed: 19940860.

20. Yu N, Li X, Song W, et al. CD4(+)CD25 (+)CD127 (low/-) T cells: a more specific Treg population in human peripheral blood. Inflammation. 2012; 35(6): 1773-1780, doi: 10.1007/ s10753-012-9496-8, indexed in Pubmed: 22752562.

21. Hartigan-O'Connor DJ, Poon C, Sinclair E, et al. Human $\mathrm{CD} 4+$ regulatory $\mathrm{T}$ cells express lower levels of the IL-7 receptor alpha chain (CD127), allowing consistent identification and sorting of live cells. J Immunol Methods. 2007; 319(1-2): 41-52, doi: 10.1016/j.jim.2006.10.008, indexed in Pubmed: 17173927.

22. Arroyo Hornero R, Betts GJ, Sawitzki B, et al. CD45RA Distinguishes CD4+CD25+CD127-/low TSDR demethylated 
regulatory $\mathrm{T}$ cell subpopulations with differential stability and susceptibility to tacrolimus-mediated inhibition of suppression. Transplantation. 2017; 101(2): 302-309, doi: 10.1097/ TP.0000000000001278, indexed in Pubmed: 28118317.

23. Seddiki N, Santner-Nanan B, Tangye SG, et al. Persistence of naive CD45RA+ regulatory T cells in adult life. Blood. 2006; 107(7): 2830-2838, doi: 10.1182/blood-2005-06-2403, indexed in Pubmed: 16332974.

24. Nettenstrom L, Alderson K, Raschke EE, et al. An optimized multi-parameter flow cytometry protocol for human $\mathrm{T}$ regulatory cell analysis on fresh and viably frozen cells, correlation with epigenetic analysis, and comparison of cord and adult blood. J Immunol Methods. 2013; 387(1-2): 81-88, doi: 10.1016/j.jim.2012.09.014, indexed in Pubmed: 23058673.

25. Mandapathil M, Lang S, Gorelik E, et al. Isolation of functional human regulatory $\mathrm{T}$ cells (Treg) from the peripheral blood based on the CD39 expression. J Immunol Methods. 2009; 346(1-2): 55-63, doi: 10.1016/j.jim.2009.05.004, indexed in Pubmed: 19450601.

26. Garcia Santana CA, Tung JW, Gulnik S. Human treg cells are characterized by low/negative CD6 expression. Cytometry A. 2014; 85(10): 901-908, doi: 10.1002/cyto.a.22513, indexed in Pubmed: 25088497.

27. Salgado FJ, Pérez-Díaz A, Villanueva NM, et al. CD26: a negative selection marker for human Treg cells. Cytometry A. 2012; 81(10): 843-855, doi: 10.1002/cyto.a.22117, indexed in Pubmed: 22949266.

28. Douaisi M, Resop RS, Nagasawa M, et al. CD31, a valuable marker to identify early and late stages of $\mathrm{T}$ Cell differentiation in the human thymus. J Immunol. 2017; 198(6): 2310-2319, doi: 10.4049/jimmunol.1500350, indexed in Pubmed: 28159903.

29. Motamedi M, Xu L, Elahi S. Correlation of transferrin receptor (CD71) with Ki67 expression on stimulated human and mouse T cells: The kinetics of expression of $\mathrm{T}$ cell activation markers. J Immunol Methods. 2016; 437: 43-52, doi: 10.1016/j. jim.2016.08.002, indexed in Pubmed: 27555239.

30. Sprangers B, DeWolf S, Savage TM, et al. Origin of enriched regulatory $T$ cells in patients receiving combined kidney-bone marrow transplantation to induce transplantation tolerance. Am J Transplant. 2017; 17(8): 2020-2032, doi: 10.1111/ ajt.14251, indexed in Pubmed: 28251801.

31. Tanaka A, Sakaguchi S, Tanaka A, et al. Regulatory T cells in cancer immunotherapy. Cell Res. 2017; 27(1): 109-118, doi: 10.1038/cr.2016.151, indexed in Pubmed: 27995907.
32. Curotto de Lafaille MA, Kutchukhidze N, Shen S, et al. Adaptive Foxp3+ regulatory T cell-dependent and -independent control of allergic inflammation. Immunity. 2008; 29(1): 114-126, doi: 10.1016/j.immuni.2008.05.010, indexed in Pubmed: 18617425.

33. Horwitz DA, Zheng SG, Gray JD. Natural and TGF-beta-induced Foxp3(+)CD4(+) CD25(+) regulatory T cells are not mirror images of each other. Trends Immunol. 2008; 29(9): 429-435, doi: 10.1016/j.it.2008.06.005, indexed in Pubmed: 18676178.

34. Abbas AK, Benoist C, Bluestone JA, et al. Regulatory T cells: recommendations to simplify the nomenclature. Nat Immunol. 2013; 14(4): 307-308, doi: 10.1038/ni.2554, indexed in Pubmed: 23507634.

35. Dieckmann D, Plottner H, Berchtold S, et al. Ex vivo isolation and characterization of CD4(+)CD25(+) T cells with regulatory properties from human blood. J Exp Med. 2001; 193(11): 1303-1310, doi: 10.1084/jem.193.11.1303, indexed in Pubmed: 11390437.

36. Kleinewietfeld M, Starke M, Di Mitri D, et al. CD49d provides access to ,untouched" human Foxp3+ Treg free of contaminating effector cells. Blood. 2009; 113(4): 827-836, doi: 10.1182/blood-2008-04-150524, indexed in Pubmed: 18941119.

37. Silva SL, Albuquerque AS, Serra-Caetano A, et al. Human naïve regulatory T-cells feature high steady-state turnover and are maintained by IL-7. Oncotarget. 2016; 7(11): 12163-12175, doi: 10.18632/oncotarget.7512, indexed in Pubmed: 26910841.

38. Imanguli MM, Cowen EW, Rose J, et al. Comparative analysis of FoxP3(+) regulatory $\mathrm{T}$ cells in the target tissues and blood in chronic graft versus host disease. Leukemia. 2014; 28(10): 2016-2027, doi: 10.1038/leu.2014.92, indexed in Pubmed: 24577531.

39. Silva SL, Sousa AE. Establishment and maintenance of the human na ve CD4 T-cell compartment. Front Pediatr. 2016; 4: 119, doi: 10.3389/fped.2016.00119, indexed in Pubmed: 27843891.

40. Willasch AM, Salzmann-Manrique E, Krenn T, et al. Advanced flowcytometric analysis of regulatory T cells: CD127 downregulation early post stem cell transplantation and altered Treg/CD3(+)CD4(+)-ratio in severe GvHD or relapse. J Immunol Methods. 2011; 373(1-2): 36-44, doi: 10.1016/j. jim.2011.07.018, indexed in Pubmed: 21839739.

Submitted: 26 April, 2021

Accepted after reviews: 23 May, 2021

Available as AoP: 7 June, 2021 